\title{
Commodity Frontiers
}

Capitalism, Contestation, and the Transformation of the Global Countryside

The Journal of the Commodity Frontiers Initiative

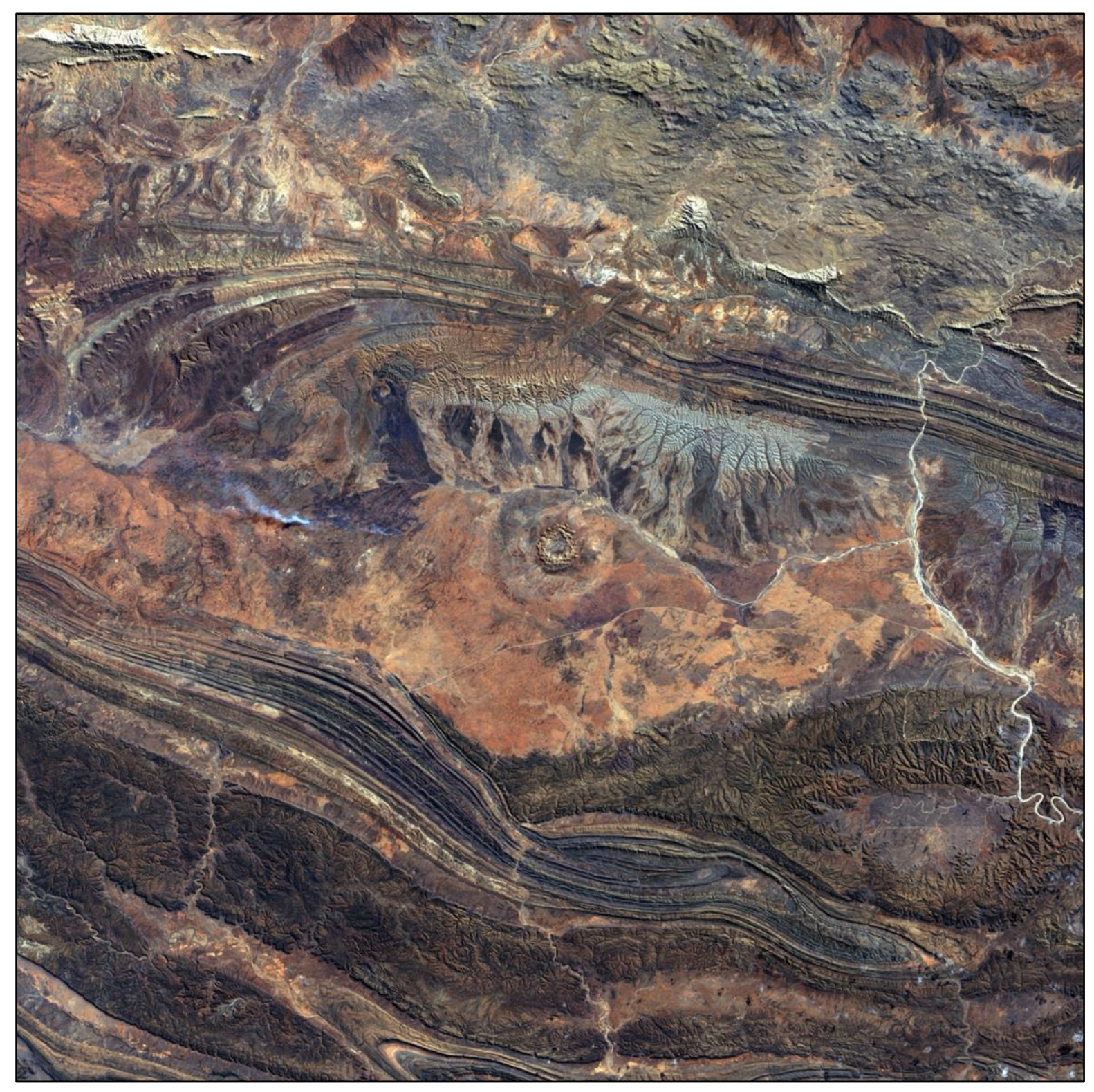

\section{Mineral Frontiers}

Issue 1, Fall 2020 


\title{
Commodity Frontiers Editorial Board
}

\author{
Mindi Schneider, Senior Editor
}

\section{Editors-in-Chief}

Sven Beckert, Ulbe Bosma, Mindi Schneider, Eric Vanhaute

\section{Section Editors}

$\underline{\text { Feature Article }}$

Kristina Dietz

Bettina Engels

Studying Commodity Frontiers

Samuël Coghe

Shaohua Zhan

Teaching Commodity Frontiers

Gayatri A. Menon

Elisabet Rasch

Historians take on the Present

Pim de Zwart

Mamoudou Sy

Simon Jackson

\section{Commodity Frontier Political Ecology \\ Andrew Curley \\ Mattias Borg Rasmussen \\ Conflicts, Frictions, and Counternarratives \\ Katie Sandwell \\ Serena Stein}

Creative Frontiers

Maarten Vanden Eynde

Marjolein Dijkman

From the Field

Hanne Cottyn

Sthandiwe Yeni

Publications

Ernst Langthaler

Rafael Marquese

Op-Eds

Mindi Schneider

Events and Announcements

Claudia Bernardi

For further information about the Editorial Board, see the CFI website at: https://commodityfrontiers.com/aboutus/. 


\section{Table of Contents}

All articles are posted online at Commodity Frontiers, or our website, commodityfrontiers.com.

\section{Editorial Introduction}

Mindi Schneider

\section{Feature Article}

Gold is not for Eating: Conflicts Related to Gold Mining in Burkina Faso

Bettina Engels

\section{Studying Commodity Frontiers}

Making Sense of Global Gold Mining

Boris Verbrugge and Maria Eugenia Robles Mengoa

Teaching Commodity Frontiers

Teaching Extraction and its Discontents: A Conversation with Anna Zalik

Gayatri Menon

Historians take on the Present

Copper, Llamas and a Virus: A Tale of Historically Entangled Frontiers

Hanne Cottyn

\section{Commodity Frontier Political Ecology}

Frontiers of the Green Energy Transition: An Interview about Lithium Mining in South

America

Maria Cariola

Conflicts, Frictions, and Counternarratives

Anti-Mining Conflicts and Degrowth

Julien-François Gerber

\section{Creative Frontiers}

On-Trade-Off: Countering Extractivism by Transnational Artist's Collaborations

Lotte Arndt and Oulimata Gueye in close exchange with the members of On-Trade-Off

From the Field

"COVID-19 has Crippled Our Struggle": An Interview with Pinky Langa

Sithandiwe Yeni

\section{Publications}

Mining and Historical Capitalism: Book Reviews

Leonardo Marques

\section{Op-Eds}

WWF's "Living Planet Report 2020" and the Long History of Capitalism

Ulbe Bosma

The End of Naïve Europe, The Rise of Green Imperialism

Alberto Vázquez Ruiz

Events and Announcements

Claudia Bernardi 


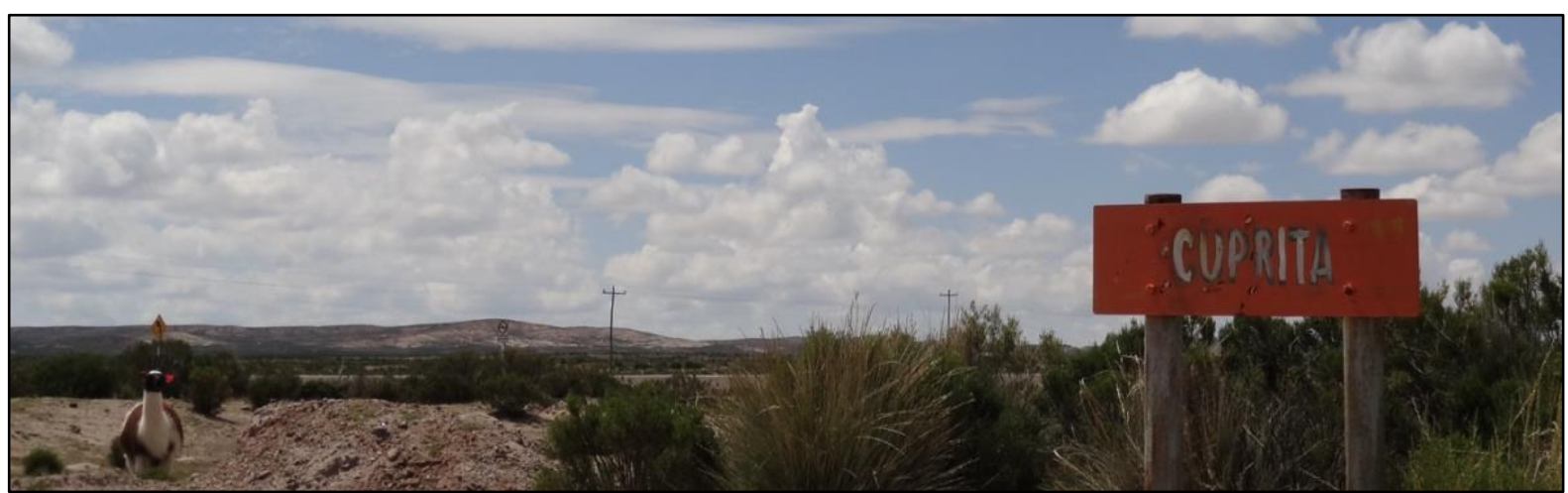

Llamas grazing behind the old signboard of the "Cuprita" copper mine, Bolivia. Source: Hanne Cottyn, 2018.

\section{Mission Statement}

Commodity Frontiers is the Journal of the Commodity Frontiers Initiative (CFI). Edited by a group of scholars and researchers from various disciplines and organizations in the CFI Network, Commodity Frontiers explores the history and present of capitalism, contestation, and ecological transformation in the global countryside. Each themed issue includes articles and interviews with experts about studying and teaching commodity frontiers in theory and in practice. The Journal features reflections and reviews on the dynamics of capitalist expansion, social change, and ecological transformation on global as well local scales, in the past and at the present.

Contributors include historians, social scientists, (political) ecologists, artists, and activists who work on global commodity production and circulation, rural societies, labor history, the history of capitalism, social metabolism, and contemporary politics, conflicts, and counternarratives in the countryside. Commodity Frontiers endeavors to carry out one of the central goals of the CFI: to provide long historical perspectives on problems that are often assumed to be modern, and to link historical and contemporary research to recast our thinking about sustainability, resilience, and crisis.

Commodity Frontiers is a biannual open-access publication housed at commodityfrontiers.com, through Commodity Frontiers in the Open Journal System at Wageningen University, and distributed through email subscriptions. Its editorial collective is committed to inclusive, antiracist, anti-sexist, decolonial scholarship and politics.

\section{Objectives}

Commodity Frontiers aims to provide accessible content from diverse perspectives on the past, present, and future of commodity frontiers and their dynamics. We feature research and educational activities undertaken by academics, artists, activists, and other civil society actors. By soliciting short contributions from our multidisciplinary and multi-sectoral networks, and distributing the open-access Journal through our website and the Open Journal System, we aim to reach a broader audience than typical academic publishing allows. We strive for "real-time" reports and reflections on contemporary issues, as well as contributions that link the past and present.

\section{Editorial Process}

The articles in Commodity Frontiers are not double-blind peer reviewed. Rather, Section Editors purposely solicit contributions related to the theme of each issue from experts in respective fields. All articles are reviewed by Section Editors and at least one Editor-in-Chief. 